\title{
Crop residue grazing and tillage systems effects on soil physical properties and corn (Zea mays L.) performance
}

\author{
M. de los A. Agostini ${ }^{1,4}$, G.A. Studdert ${ }^{2, *}$, S. San Martino ${ }^{2}$, J.L. Costa ${ }^{2}$, R.H. Balbuena ${ }^{3}$, \\ J.M. Ressia ${ }^{4}$, G.O. Mendivil ${ }^{4}$, L. Lázaro ${ }^{4}$ \\ ${ }^{1}$ Fellow Comisión de Investigaciones Cientificas, (1900) La Plata, Argentina. ${ }^{2}$ Unidad Integrada Balcarce, \\ C.C. 276, (7620) Balcarce, Argentina. ${ }^{3}$ Facultad de Ciencias Agrarias y Forestales, UNLP, (1900) La \\ Plata, Argentina. ${ }^{4}$ Facultad de Agronomía, UNCPBA, (7300) Azul, Argentina. ${ }^{*}$ Corresponding author: \\ Telephone \#: +54-2266-439100 ext. 766, E-mail address: gstuddert@balcarce.inta.gov.ar. Fax \#: +54-2266- \\ 439101. *Corresponding author: gstuddert@balcarce.inta.gov.ar
}

\begin{abstract}
Crop-livestock systems under no till (NT) could negatively affect soil physical properties and crop performance, due to the additive effects of reduced soil cover and cattle trampling due to livestock grazing, and the absence of tillage. We evaluated the effects of four grazing strategies and of a shallow tillage (ST) on soil physical properties and corn (Zea mays L.) performance for a mollisol after 15 years under crop-livestock systems under NT in Argentina. Grazing strategies evaluated were: closure $(\mathrm{C})$, one grazing $(\mathrm{OG})$, high stocking rate $(\mathrm{HR})$ and farmer's management (FM), and the tillage systems were: NT and ST. Bulk density (BD), penetration resistance (PR), hydraulic conductivity $\left(k_{s}\right)$, plant population, surface root distribution, aboveground dry matter accumulation, aboveground total N (TN) accumulation and corn yield were evaluated. High stocking rate and FM increased RP. On the other hand, ST decreased PR and BD and increased $k_{s}$. Corn yield was higher under ST than under NT, and under HR than under the other grazing strategies. Total N accumulation was higher under HR than under the rest of grazing strategies. Rational grazing management and use of tillage systems on resilient soils could have prevented soil physical properties be affected beyond critical thresholds.
\end{abstract}

Keywords: crop, tillage, trampling 


\section{Introduction}

Soil compaction is one of the major problems of modern agriculture and it occurs in a wide range of soils and climates. Some soil textural classes are more susceptible to harmful compaction than others, especially those with high silt content (Álvarez and Steinbach, 2009) which show poor resilience.

This process adversely affects soil physical properties such us, bulk density (BD), infiltration rate and penetration resistance (PR) (Greenwood and Mac Kenzie, 2001) and consequently, affects root growth and crop yield (Hamza and Anderson, 2005). Cattle trampling, machinery traffic, and inappropriate soil management have been reported to cause soil compaction (Botta et al., 2004; Hamza and Anderson, 2005).

Changes in soil physical properties caused by grazing have received little research attention in comparison with compaction due to cropping (Greenwood and McKenzie, 2001). The depth of trampling-induced soil compaction ranges from 2.5 to $20 \mathrm{~cm}$ depth (Hamza and Anderson, 2005) affecting soil physical properties and crop growth, particularly under wet soil condition (Di et al., 2001). The magnitude of trampling effects is related to the pressure exerted on the soil, which is a function of animal mass and foot size, grazing intensity, soil characteristics (texture, organic matter (OM), soil water content (WC)), and soil residue cover. Depending on the magnitude of trampling effects on soil physical properties, it should be recommended either to remove the animals from the field or to implement tillage operations to reverse the effects (Greenwood and McKenzie, 2001; Hamza and Anderson, 2005).

No-till (NT) has become a popular conservation practice in recent years in Argentina, occupying at present about $70 \%$ of the surface under annual cropping (Álvarez and Steinbach, 2009). No-till contributes. to reduce or prevent erosion problems, and degra- dation of soil physical and chemical properties. On the other hand, is contributes to increase soil water storage because the soil is not tilled and crop residues are left on the surface. Crop residues on soil surface are the major advantage of NT (Lal et al., 1994). However, one of the reported disadvantages of NT is soil compaction caused by traffic intensity of heavy machinery, especially when the operations are carried out on wet soil or with high tire-inflation pressure (Botta et al., 2004). Furthermore, NT is associated with less N availability to the crops (Dominguez et al., 2009).

Crop-livestock systems under NT, where crop residues are grazed, are being implemented in Argentina and in some other parts of the world. These systems could increase economic return as well as the diversification of production (Franzluebbers and Stuedemann, 2008). As mentioned before, soil physical properties and crop performance could be negatively affected by integrated systems due to less soil cover during animal grazing and to the absence of tillage under NT.

Even though surface residue cover reduces cattle trampling impact (Greene et al., 1994), stubble grazing reduces residue cover and increases the exposure to trampling effects. Therefore, for the implementation of crop-livestock systems under NT, management practices that reduce the additive effect of trampling and traffic should be considered. Grazing management to ensure a minimum surface residue mass to diminish trampling effects (Franzluebbers and Stuedemann, 2008) and surface tillage (ST) before planting (Munkholm et al., 2003) are recommended practices when treading and NT are expected to result in detrimental soil physical conditions for crop growth. This would contribute to maintaining soil health and improving crop performance and both profitability and environmental sustainability would be improved (Franzluebbers and Stuedemann, 2008). 
Crop-livestock systems effects on soil physical properties and crop performance have not been widely investigated. The aim of this study was to evaluate the effect of trampling of animals grazing crop stubble and NT and ST on some soil surface physical properties and on the performance of corn (Zea mays L.). The experiment was carried out on soils with high OM content and loam clay surface texture.

\section{Materials and methods}

\subsection{Site description}

Experimental site was established in 2006 at "Los Ángeles" farm in Azul, Buenos Aires, Argentina (37 $7 ` 46 ” \mathrm{~S} ; 59^{\circ} 44^{`} 23^{\prime}$ W). The soil was a fine clayey, mixed, thermic Typic Argiudoll (Soil Taxonomy) or Luvic Phaeozem (FAO Classification), with a slope ranging from $3 \%$ to $5 \%$. Surface horizon texture is loam clay and its OM content ranged from $6.1 \%$ in the top $0-10 \mathrm{~cm}$ to $4.3 \%$ at $10-20 \mathrm{~cm}$ (Crespo, J. personal communication).

Prior to the establishment of the experiment, the site had been under pasture from 1979 to 1992. Since 1992 an integrated crop-livestock system under NT had been implemented. Crop rotation was wheat (Triticum aestivum L.) / corn. Wheat and corn stubble, volunteer wheat, and weeds have been grazed during winter seasons by breeding cows.

\subsection{Treatments and experimental design}

The experiment was conducted with a split block design (also known as a strip plot) with two treatment factors and two replications. Treatment factors were: grazing strategy (four levels) and tillage system for corn planting (two levels). Tillage system levels were: NT and ST (disc harrow, $10 \mathrm{~cm}$ depth).
Grazing strategy levels were: C) Closure: not grazed; OG) One grazing: the animals (breeding cows) entered the plot to graze volunteer wheat and wheat stubble during twelve days (90 days after wheat harvest) with regular stocking rate, after grazing, the animals were removed and did not enter again, this grazing is referred to as initial grazing and coincided with the farmer's grazing period; HR) High stocking rate: initial grazing as for $\mathrm{OG}$ and a second grazing period for one week (250 days after wheat harvest) with high stocking rate; and FM) Farmer's management: initial grazing as for OG and a second continuous grazing period until one month before corn planting with regular stocking rate. The regular stocking rate was 4 animals ha ${ }^{-1}$ and the high stocking rate was 12 animals $\mathrm{ha}^{-1}$. The average weight of the animals was $420 \mathrm{~kg}$.

Six sampling points were defined in each subplot and were located $10 \mathrm{~m}$ away one from each other and from the experimental unit boundaries. Before the tillage system was applied, measurements were made in each of the grazing strategy plots at the twelve (in total) sampling points.

One month before corn planting, weeds were controlled with glyphosate [N-(phosphonomethyl) glycine] and tillage operations were applied to ST strips. On October 12, 2006, corn hybrid Ax 884 IT (NIDERA) was planted with a population of 75000 seeds $\mathrm{ha}^{-1}$ and a fertilizer rate of $16 \mathrm{~kg} \mathrm{~N} \mathrm{ha}^{-1}$ and 18 $\mathrm{kg} \mathrm{P} \mathrm{ha-1}$ as diamonium phosphate was applied next to the seeds. Additional $69 \mathrm{~kg} \mathrm{~N}^{-1}$ were surface broadcasted as urea at corn six leaf stage (V6) (Ritchie and Hanway, 1982).

\subsection{Soil determinations}

All soil variables were determined at three times: 1: one month before corn planting; 2: Corn V6 stage, and 3: six months after corn harvest. Soil physical properties assessed were: 
Bulk density: Soil samples were taken from 0 to 5 and 5 to $15 \mathrm{~cm}$ depth layers with a $44.7 \mathrm{~mm}$ diameter soil core sampler (Doran and Mielke, 1984). Soil core volume was registered and WC determined gravimetrically, to calculate BD. One sample was taken per sampling point.

Penetration resistance: Cone index (CI) was measured with a Rimick CP20 (Toowoomba, Queensland, Australia, ASAE Standard S313) recording penetrometer from soil surface to $15 \mathrm{~cm}$ depth, at $2.5 \mathrm{~cm}$ depth intervals. The CI obtained from each sampling point and at each depth interval is the average of three measurements.

Saturated hydraulic conductivity $\left(k_{s}\right)$ : Infiltration rate was measured with a simple ring infiltrometer (Ankeny, 1986). Four measurements were done before planting in each grazing strip and after corn planting two measurements were done in each experimental unit.

Saturated hydraulic conductivity was calculated using the model (method 2) proposed by Wu et al. (1999). To estimate model parameters, the cumulative infiltration data were adjusted to an exponential-plateau model through non linear regression (NLIN procedure, of the Statistical Analysis System (SAS) (Littell et al., 2006). The data of $k_{s}$ were $\log _{10}$-transformed due to variance heterogeneity. The transformed variable was called transformed saturated hydraulic conductivity $\left(k_{s} t\right)$.

\subsection{Crop determinations}

Plant population: Number of plants achieved was quantified in twelve $7.15 \mathrm{~m}$-long rows at corn physiological maturity (PM, Ritchie and Hanway, 1982). Surface root distribution: It was determined by the grid method proposed by Bohm (1979). For this determination a square $28 \times 28 \mathrm{~cm}$ frame with $2 \times 2 \mathrm{~cm}$ cells was used. Two holes per experimental unit were dug, with a corn plant in the middle. Presence or absence of roots within each cell was registered. This determination was done at corn V6 stage.

Aboveground dry matter accumulation (DMA): Thirty plants were cut at ground level at V6 and PM corn stages. Plant samples were weighed and then dried at $60^{\circ} \mathrm{C}$. Dry weight was registered, and dry matter (DM) content and accumulation were calculated.

Aboveground total $N$ accumulation (TN): A fraction of grain and of the rest of the plant samples taken at PM was ground to pass a $1 \mathrm{~mm}$ sieve. Nitrogen content of each fraction was determined by the Dumas dry combustion method at $950^{\circ} \mathrm{C}$ using a TruSpec analyzer (LECO, St. Joseph, Michigan, USA). Aboveground total $\mathrm{N}$ accumulation was calculated from grain $\mathrm{N}$ content and grain yield plus rest of the plant $\mathrm{N}$ content and aboveground DMA (without grain).

Corn yield: Grain yield of corn was determined by collecting ears from $20 \mathrm{~m}^{2}$ of each experimental unit and threshing them with a stationary thresher. Yield was corrected to $14.5 \%$ moisture content.

\subsection{Statistical analyses}

Soil variable data were analyzed through a linear mixed model which takes into account the experimental design employed and considers the sampling times as repeated measures. Interaction with tillage system at sampling times 2 and 3 and comparisons between sampling times 1 and 2 were analyzed through orthogonal contrast. The analyses for BD and PR were done at each depth.

Corn variables were analyzed through a linear mixed model considering different random errors associated with the experimental design. All the analyses were performed using the MIXED procedure of SAS (Littell et al., 2006). For all statistical analysis the significance level was 0.05 . 


\section{Results and discussion}

\subsection{Rainfall and soil water content (WC) during the experiment}

Precipitation from April/2006 to September/2006 $(231.7 \mathrm{~mm})$ was lower than the $91 \mathrm{yr}$ average precipitation $(292.5 \mathrm{~mm})$. Precipitation during the initial grazing period was $14 \mathrm{~mm}$. On the other hand, during the FM grazing strategy the precipitation registered was $58.5 \mathrm{~mm}$.

Precipitation during the 2006/2007 corn growing season (from corn planting to harvest) $(778 \mathrm{~mm}$ ) was higher than the $91 \mathrm{yr}$ average precipitation $(519 \mathrm{~mm}$; 1911-2001). There was a slight water deficit during the critical period of grain yield determination.

There was no interaction nor grazing, tillage or sampling time effects on WC at any depth. At all sampling times $\mathrm{WC}$ was above field capacity $(27 \% \mathrm{v} / \mathrm{v})$.

\subsection{Grazing strategies and tillage system effects on soil physical properties}

Grazing system effects on soil physical properties have been reported to be strongly associated with stocking rate. Also, it has been observed that BD, and PR increase whereas infiltration rate decreases (Greenwood et al., 2001) when stocking rate or/and grazing period increase. On the contrary, Donkor et al. (2002) found the same degree of compaction under a short grazing period with high stocking rate and under a long grazing period with low stocking rate.

In our experiment, with different stocking rates and grazing periods, grazing strategy $x$ tillage system interaction effect on soil physical properties evaluated was not significant. One month before corn planting, $k_{s} t$ was not significantly affected by grazing strategies. However, coinciding with generally reported trends when no animals were present on the field ( $\mathrm{C}$ treatment) the $k_{s} t$ was slightly higher $\left(k_{s} t=1.92 \pm 0.09\right)$ than under OG, HR or FM $\left(k_{s} t\right.$ average $\left.=1.74 \pm 0.07\right)$. Fernandez et al (2006) found higher $k_{s}$ in non grazed plots in comparison with grazed plots in soils with textural characteristics similar to the one used in this study. On the other hand, Pietola et al. (2005) reported that $k_{s}$ was lowest under grazed plots in clay and sand loam soils.

Bulk density was not significantly affected by grazing strategies (sampling time 1), except at $0-5 \mathrm{~cm}$ depth (Table 1). Despite the expected result, BD under $\mathrm{HR}$ and FM was significantly lower than under $\mathrm{C}$ or OG at 0-5 cm depth (Table 1, sampling time 1). Similar behavior was observed in 5-15 cm depth (although the difference between grazing strategies was not significant). Our results disagree with those reported by other authors (Greenwood and Mac Kenzie, 2001; Franzluebbers and Stuedemann, 2008) who showed $\mathrm{BD}$ increases due to animal treading.

Table 1. Bulk density at $0-5 \mathrm{~cm}$ and $5-15 \mathrm{~cm}$ depth layers for different grazing strategies $(\mathrm{C}$ : not grazed; OG: One grazing; HR: high stoking rate; FM: farmer's management), at sampling time 1 (one month before corn planting), sampling time 2 (corn V6 stage), and sampling time 3 (six months after corn harvest). For each depth, different letters indicate significant differences $(p<0.05)$.

\begin{tabular}{|c|c|c|c|c|}
\hline \multirow{3}{*}{ Depth } & \multirow{3}{*}{$\begin{array}{l}\text { Grazing } \\
\text { strategy }\end{array}$} & \multicolumn{3}{|c|}{ Bulk density } \\
\hline & & \multicolumn{3}{|c|}{ Sampling time } \\
\hline & & 1 & 2 & 3 \\
\hline \multicolumn{2}{|l|}{$--\mathrm{cm}--$} & \multicolumn{3}{|c|}{ - } \\
\hline \multirow{4}{*}{$0-5$} & $\mathrm{C}$ & $1.31 \mathrm{a}$ & $1.31 \mathrm{a}$ & $1.20 \mathrm{a}$ \\
\hline & OG & $1.31 \mathrm{a}$ & $1.29 \mathrm{a}$ & $1.12 \mathrm{a}$ \\
\hline & HR & $1.26 \mathrm{~b}$ & $1.23 \mathrm{a}$ & $1.17 \mathrm{a}$ \\
\hline & FM & $1.23 \mathrm{~b}$ & $1.28 \mathrm{a}$ & $1.16 \mathrm{a}$ \\
\hline \multirow{4}{*}{$5-15$} & $\mathrm{C}$ & $1.21 \mathrm{a}$ & $1.26 \mathrm{a}$ & $1.20 \mathrm{a}$ \\
\hline & OG & $1.17 \mathrm{a}$ & $1.21 \mathrm{a}$ & $1.16 \mathrm{a}$ \\
\hline & HR & $1.17 \mathrm{a}$ & $1.21 \mathrm{a}$ & $1.16 \mathrm{a}$ \\
\hline & FM & $1.15 \mathrm{a}$ & $1.21 \mathrm{a}$ & $1.16 \mathrm{a}$ \\
\hline
\end{tabular}


Penetration resistance was significantly affected by grazing strategies (sampling time 1) only in the first $5 \mathrm{~cm}$ depth, being higher under HR and FM than under $\mathrm{C}$ and $\mathrm{OG}$ (Figure 1). This agrees with the results reported by da Silva et al (2003). The effects of livestock trampling are greater when surface cover declines (Greene et al., 1994) and when soil WC increases (Di et al., 2001).

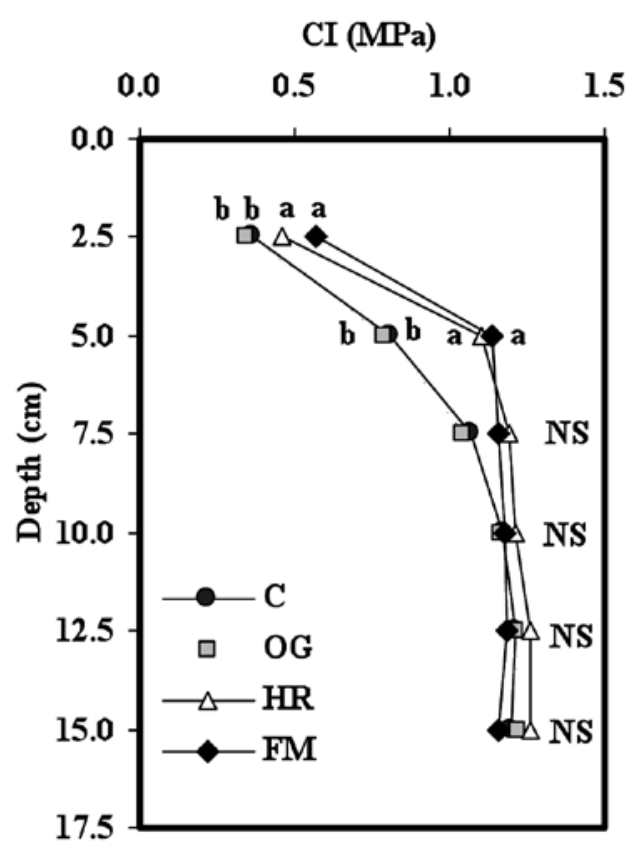

Figure 1. Penetration resistance expressed as cone index (CI) at 0-15 cm depth layer for different grazing strategies (C: not grazed; OG: One grazing; HR: high stoking rate; FM: farmer's management) at sampling time 1 (one month before corn planting). For each depth, different letters indicate significant differences $(p<0.05)$. NS: $p>0.05$.
During the second grazing (HR and FM), the forage source comprised weeds, volunteer wheat re-growth and some wheat stubble. Re-entry of animals after the initial grazing under HR and FM caused a fast loss of cover and consequently a higher exposure of the soil to cattle trampling effects (Greene et al., 1994). However, differences in PR between grazing strategies were negligible from the agronomic point of view. The difference between C-OG and HR-FM was 0.16 $\mathrm{MPa}$ at $2.5 \mathrm{~cm}$ depth and $0.32 \mathrm{MPa}$ at $5.0 \mathrm{~cm}$ depth.

After tillage system application (sampling time 2), neither grazing strategy $x$ tillage system interaction nor grazing strategy effects were significant. The extent of the effect of grazing strategies on soil physical properties was less in comparison with the effect of tillage system. Sampling done three months after tillage system application (at V6, sampling time 2), showed that ST improved soil physical properties by decreasing PR (Figure 2) and BD (Table 2, sampling time 2), and increasing $k_{s}$. Penetration resistance was significantly affected by the tillage system. Surface tillage showed lower PR up to $12.5 \mathrm{~cm}$ depth, but below this depth no difference between tillage systems was observed (Figure 2). Our results agree with those reported by Botta et al. (2004). Taboada et al. (1998) reported that NT increases significantly PR in sandy loam and silty clay loam soils. These higher PR's could not be attributed to compaction but rather to soil hardening. This process could be considered a consequence of ageing of undisturbed agricultural topsoils. 


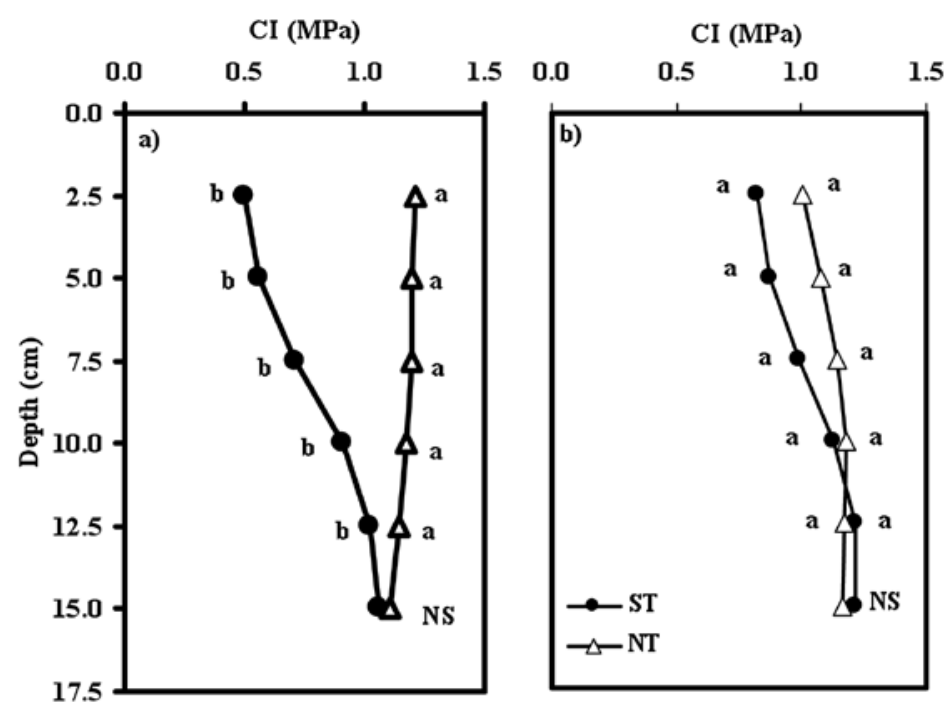

Figure 2. Penetration resistance expressed as cone index (CI) at 0-15 $\mathrm{cm}$ depth layer at a) sampling time 2 (corn V6 stage) and b) sampling time 3 (six months after corn harvest) for two tillage systems (NT: no till; ST: shallow tillage). For each depth, different letters indicate significant differences $(p<0.05)$. NS: $p>0.05$.

As previously mentioned, BD was not significantly affected by tillage systems (Table 2, sampling time 2).However, our result follow the generally reported trend of soil BD increases because of NT implementation (Taboada et al., 1998).

Table 2. Bulk density at $0-5 \mathrm{~cm}$ and $5-15 \mathrm{~cm}$ depth layers for two tillage systems (ST: shallow tillage; NT: no till) at sampling time 2 (corn V6 stage) and sampling time 3 (six months after corn harvest). For each depth, different letters indicate significant differences $(p<0.05)$.

\begin{tabular}{cccc}
\hline \multirow{2}{*}{ Depth } & \multirow{2}{*}{$\begin{array}{c}\text { Tillage } \\
\text { system }\end{array}$} & \multicolumn{2}{c}{ Bulk density } \\
\cline { 3 - 4 } & & \multicolumn{2}{c}{ Sampling time } \\
\cline { 3 - 4 } & & $--------M g$ m $^{-3}--------$ \\
\hline$---c m---$ & & $1.30 \mathrm{a}$ & $1.15 \mathrm{a}$ \\
\multirow{2}{*}{$0-5$} & $\mathrm{NT}$ & $1.25 \mathrm{a}$ & $1.16 \mathrm{a}$ \\
& $\mathrm{ST}$ & $1.23 \mathrm{a}$ & $1.19 \mathrm{a}$ \\
\multirow{2}{*}{$5-15$} & $\mathrm{NT}$ & & \\
& $\mathrm{ST}$ & $1.21 \mathrm{a}$ & $1.14 \mathrm{a}$ \\
\hline
\end{tabular}

Transformed saturated hydraulic conductivity was significantly affected by tillage systems (Figure 3, sampling time 2). Transformed saturated hydraulic conductivity was higher under ST $\left(2.04 \pm 0.24, k_{\mathrm{s}}=\right.$ $\left.123.42 \mathrm{~mm} \mathrm{~h}^{-1}\right)$ than under NT $\left(1.32 \pm 0.37, k_{\mathrm{s}}=31.24\right.$ $\mathrm{mm} \mathrm{h}^{-1}$ ). In agreement with Ferreras et al. (2000) and Sasal et al. (2006), $k_{s} t$ under NT was lower than under tillage. This behavior has been reported by others authors (Sasal et al., 2006), who attributed this tendency to horizontal re-orientation (parallel to the soil surface) of macropores associated to NT. Soil pore dynamics may be reflected in $\mathrm{BD}$ and $\mathrm{PR}$ variations. As mentioned above, in our experience, NT showed higher PR (Figure 2) and BD (Table 2, sampling time 2) than ST, consequently, these properties may have affected $k_{s} t$. 


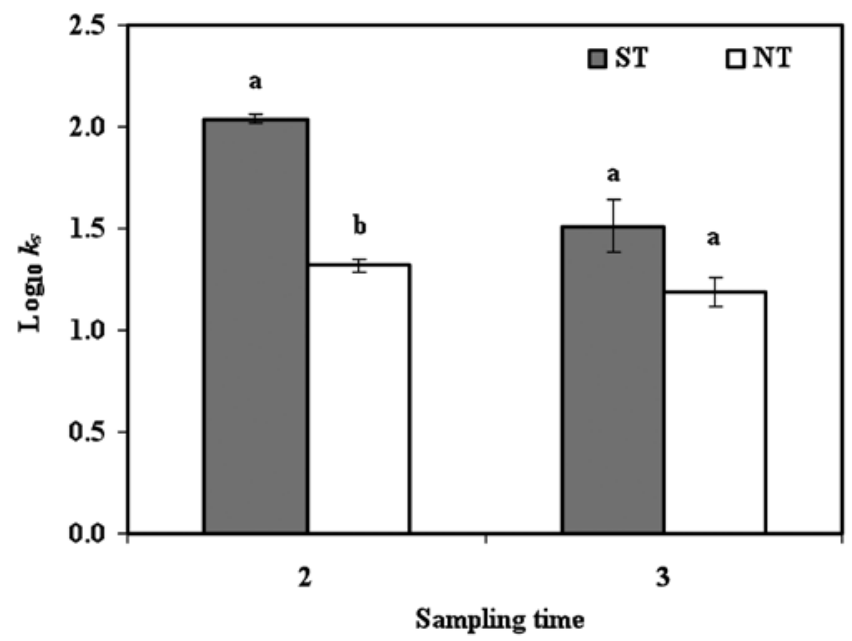

Figure 3. Transformed saturated hydraulic conductivity $\left(\log _{10} \mathrm{k}_{\mathrm{s}}\right)$ at sampling time 2 (corn V6 stage) and sampling time 3 (corn physiological maturity) for two tillage systems (ST: shallow tillage; NT: no till). For each sampling time, different letters indicate significant differences $(p<0.05)$.

Six months after crop harvest (sampling time 3), tillage system effect on soil physical properties disappeared. In general, BD (Table 2, sampling time 3), $\mathrm{RP}$ (Figure $2 \mathrm{~b}$ ) and $k_{\mathrm{s}} t$ (Figure 3, sampling time 3) showed lower values than in sampling time 2 . The recovery of the initial soil condition can be explained by the high OM content and the loam clay surface horizon texture. Soil physical properties behavior depends to a great extend, on its carbon stock (Domínguez et $a l ., 2009$ ) and texture (Alvarez and Steinbach, 2009). Organic matter may increase aggregate strength and thus help prevent soil pore structure degradation, and consequently the impact of compaction. On the other hand, OM may also improve soil aggregation, resulting in a higher total porosity and wider poresize distribution. This characteristic determines the magnitude of soil mechanical resilience (Zhang et al., 2005). Another explanation could be that corn root growth could have helped to ameliorate soil physical properties (Domínguez et al., 2001).These character- istics could have helped the soil to recover the physical condition after soil disturbance.

In summary, neither BD nor PR increases reached critical threshold for root growth. Regarding PR, the threshold is $2 \mathrm{MPa}$ (Gupta and Allmaras, 1987) whereas for $\mathrm{BD}$ critical value has been demonstrated to be $1.4 \mathrm{Mg} \mathrm{m}^{-3}$ for corn root growth (Chidichimo et al., 1997). Anyway, BD, PR and $k_{s} \mathrm{t}$ values indicated that the soil did not show structural problems due to grazing strategies and/or tillage systems. These results could be attributed to the good structure and high $\mathrm{OM}$ content of this mollisol, and to the rational application of grazing strategies and tillage systems along time.

\subsection{Grazing and tillage system effects on corn crop behavior}

Statistical analyses did not show significant interaction between tillage system and grazing strategy nor a significant effect of grazing strategies on the number 
of plants achieved, surface root distribution and DMA (neither at V6 nor at PM). Also, neither the number

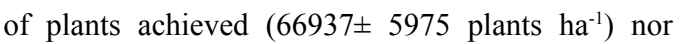
surface root distribution were significantly affected by tillage system (Figure 4a). However, a relatively higher number of roots under ST than under NT (Figure 4a), was observed. This behavior can be attributed to the observed lower BD (Table 2, sampling time 2) and PR (Figure 2) under ST, since root density decreases with increasing PR and BD (Ferreras et al., 2000). Increases in these soil parameters can finally be reflected in lower crop yield (Ferreras et al., 2000; Hamza and Anderson, 2005). Rizalli (1998) working on a physically degraded like soil due to previous long term aggressive cropping, did not find any difference in corn root growth between NT and conventional tillage. Therefore, given the better soil physical conditions and the precipitation distribution in our experiment, no differences between tillage systems could have been expected. Figure $4 \mathrm{~b}$ shows surface root distribution for the different grazing strategies and it can be seen lower number of roots under $\mathrm{C}$ than under OG, FM, and HR. Surface root distribution was $\mathrm{C}<\mathrm{OG}<\mathrm{FM}<\mathrm{HR}$, which relates to the $\mathrm{BD}$ value (Table 2, sampling time 2).As mentioned before, increases in BD and PR affect normal root growth and consequently crop yield (Hamza and Anderson, 2005). In our experiment, the number of roots was greater when BD declined. This difference was unimportant from an agronomic point of view.
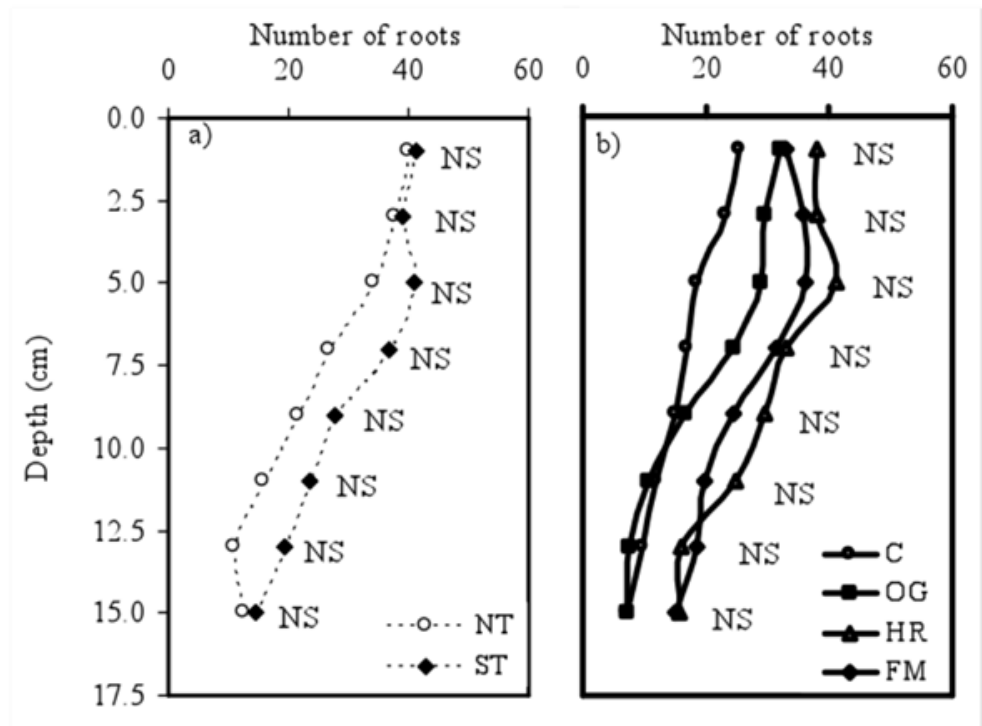

Figure 4. Surface corn root distribution at sampling time 2 (corn V6 stage) up to $15 \mathrm{~cm}$ depth under a) two tillage systems (ST: shallow tillage; NT: no till) and b) four grazing strategies (C: not grazed; OG: one grazing; HR: high stoking rate; FM: farmer's management). For each depth, different letters indicate significant differences $(p<0.05)$. NS: $p>0.05$. 
At V6 (sampling time 2), DMA under NT (2279 $\mathrm{kg} \mathrm{DM} \mathrm{ha-1)}$ was significantly lower than under ST (3096 kg DM ha ${ }^{-1}$ ), since plant sampling had been done at one time and plants were at different phenological stages between tillage systems. However, at PM, (sampling time 3) tillage systems did not affect DMA (ST: $15935 \mathrm{~kg} \mathrm{DM} \mathrm{ha}^{-1}$; NT: $15290 \mathrm{~kg}$ DM ha $\left.{ }^{1}\right)$. These results agree with those reported by Rizzalli (1998) and Domínguez et al. (2001).

Feces and urine deposition from livestock increase within-farm nutrient cycling (Franzluebbers et al., 2000). In our experiment, $\mathrm{TN}$ accumulation was significantly affected by grazing strategies, being TN accumulation higher under $\mathrm{HR}\left(215.4 \mathrm{~kg} \mathrm{~N} \mathrm{ha}^{-1}\right)$ than under $\mathrm{C}\left(147.8 \mathrm{~kg} \mathrm{~N} \mathrm{ha}^{-1}\right)$, OG (170.0kg N ha' $\left.{ }^{-1}\right)$ and FM (202.4 kg N ha-1). Although TN was not significantly affected by tillage system, it showed a trend to slightly higher TN under ST than under NT $(172.8 \mathrm{~kg}$ $\mathrm{N} \mathrm{ha}^{-1}$ and $195.0 \mathrm{~kg} \mathrm{~N} \mathrm{ha}^{-1}$, respectively).

Grazing crop stubble does not imply a complete removal of biomass from the plant-soil system since much of the ingested forage is transformed into manure that is returned to the field (Quiroga et al., 2009), contributing to total carbon and $\mathrm{N}$ stock recycling (Maughan et al., 2009). Franzluebbers et al. (2000) reported that areas with high animal presence get enriched with soil carbon and $\mathrm{N}$ probably because of the high organic deposition from cattle defecation and urination. This would have increased fertility and subsequent forage growth. In our experiment, grain yield was the only crop parameter significantly affected by tillage systems and by grazing strategies. Grain yield under HR and FM (8.510 kg ha-1 and $7.903 \mathrm{~kg} \mathrm{ha}^{-1}$, respectively) was higher than under $\mathrm{C}$ and OG (6.439 $\mathrm{kg} \mathrm{ha}^{-1}$ and $7.576 \mathrm{~kg} \mathrm{ha}^{-1}$, respectively) which was also reflected in higher TN. It is important to highlight that HR and FM treatments had higher animal presence in comparison with $\mathrm{C}$ and OG. It is worth noting that both grain yield and $\mathrm{TN}$ for grazing strategies could be ordered as $\mathrm{C}<\mathrm{OG}<\mathrm{FM}<\mathrm{HR}$ which in turn relates to the time of presence and the stocking of the animals on the field. Therefore, high animal presence leads to organic deposition from cattle (feces and urine), contributing to $\mathrm{N}$ stock recycling and increased crop yield.

Corn yield is mostly related to water and $\mathrm{N}$ availability during the crop growing season (Barbieri et $a l ., 2008)$. In our experiment, precipitation during this period was unevenly distributed but it reasonably covered crop water requirement (data not shown). However, a slight water deficit occurred during a critical period for corn (January). In general, soils under NT have higher water availability than bare soils, which might contribute crops tolerating water deficits during critical periods.

Contrarily to what it could have been expected because of such slight water deficit, corn grain yield under ST was significantly higher than under NT $(8090$ $\mathrm{kg} \mathrm{ha}^{-1}$ and $7124 \mathrm{~kg} \mathrm{ha}^{-1}$, respectively). Stubble cover, absence of tillage, low mineralization rate and high microbial activity under NT promote $\mathrm{N}$ loss (volatilization, denitrification, leaching) and low $\mathrm{N}$ availability (Domínguez et al., 2001; 2009). On the other hand, $\mathrm{N}$ fertilization rate was $85 \mathrm{~kg} \mathrm{~N} \mathrm{ha}^{-1}$ for NT and ST plots, but tilling the soil increases $\mathrm{N}$ mineralization (Domínguez et al., 2009) and supposedly the corn under ST had more $\mathrm{N}$ available. Therefore, given the distribution of rainfall and the low rate of $\mathrm{N}$ fertilization, the lower yield under NT could be attributed to a limited $\mathrm{N}$ availability.

\section{Conclusions}

Rational grazing management and use of tillage systems on resilient soils (high soil OM content, and loam clay texture) could have prevented soil physical properties to be affected beyond critical thresholds. On the other hand, according to the $\mathrm{N}$ accumulation and grain yield differences among grazing strategies, 
we inferred that they influenced $\mathrm{N}$ dynamics and availability because of urine and manure droppings. However, $\mathrm{N}$ availability should be monitored in order to detect $\mathrm{N}$ unavailability and its effect on crop behavior in crop-livestock systems under NT.

\section{Acknowledgements}

We express our gratitude to Azul-Chillar CREA Group, ESTANCIA "LOS ANGELES" and FACULTAD DE AGRONOMIA (UNCPBA) and to Ricardo Illarragorri, Jorge Celiberti, Cristina de Pablo, Oscar Basterrechea and Germán Dominguez for their collaboration.

\section{References}

Álvarez, R., Steinbach, H. S. 2009. A review of the effects of tillage systems on some soil physical properties, water content, nitrate availability and crop yield in the Argentine Pampas. Soil Till. Res. 104:1-16.

Ankeny, M. 1986. Methods and theory for unconfined infiltration measurements in Klute,A (ed). 1986. Methods of soil analysis. Part I: Physical and mineralogical methods. 2nd ed. ASA and SSSA, Madison, WI. Agron. Monogr. 9. Pp 123-141

Barbieri, P. A., Echeverría, H. E., Saínz Rozas, H. R. 2008. Presidedress soil nitrogen test for no tillage maize at different row spacing. Agron. J. 100:1101-1105.

Bohm, W. 1979. Methods of studying root systems. Ecol. Stud., 33.

Botta, G. F., Jorajuria, D., Balbuena, R. H., Rosatto, D. 2004. Mechanical and cropping behavior of direct drilled soil under different traffic intensities: effects on soybean (Glycine max L) yields. Soil Till. Res. 78:53-58.
Chidichimo, H., Asborno, M., Aragón, A. 1997. Enraizamiento de maíz: respuesta genotípica a tratamientos de compactación y humedad del suelo. Proceedings $6^{\circ}$ Congreso Nacional de Maíz. Pergamino.Tomo III: 173-179.

da Silva, A. P., Imhoff, S., Corsi, M. 2003. Evaluation of soil compaction in an irrigated short duration grazing system. Soil Till. Res. 70: 83-90.

Di, H. J., Cameron, K. C., Milne, J., Drewry, J. J., Smith, N. P., Hendry, T., Moore, S., Reijnen, B. 2001. A mechanical hoof for simulating animal treading under controlled conditions. New Zeal. J. Agric. Res. 44:111-116.

Domínguez, G. F., Studdert, G. A., Echeverría, H. E., Andrade, F. H. 2001. Sistemas de cultivo y nutrición nitrogenada en maíz. Ciencia del suelo. 19:47-56.

Domínguez, G. F., Diovisalvi, N. V., Studdert, G. A., Monterubbianesi, M. G. 2009. Soil organic C and $\mathrm{N}$ fractions under continuous cropping with contrasting tillage systems on mollisols of the southeastern Pampas. Soil Till. Res. 102:93-100.

Donkor, N. T., Gedir, J. V., Hudson, R. J., Bork, E. W., Chanasyk, D., Naeth, M. A. 2002. Impacts of grazing systems on soil compaction and pasture production in Alberta. Can. J. Soi Sci. 82: 1-8.

Doran J. W., Mielke, L. N. 1984. A rapid, low cost method for determination of soil bulk density. Soil Sci. Soc. Am. J. 48:717-719.

Fernandez, P. L., Alvarez, C. R., Correa Luna, M., Taboada, M. 2006. Propiedades físicas en sistemas de producción mixta y de agricultura contínua en SD. Proceedings 20th Congreso Argentino de la Ciencia del Suelo. September 20-23, 2006, Salta-Jujuy, Argentina, 5 p. (in CD-ROM).

Ferreras, L. A., Costa, J. L., Garcia, F. O., Pecorari, C. 2000. Effect of no-till on some soil physical properties of a structural degraded Petrocalcic 
Paleudoll of the southern "Pampa" of Argentina. Soil Till. Res.54:31-39.

Franzluebbers, A. J., Stuedemann, J. A. 2008. Early response of soil organic fraction to tillage and integrated crop-livestock production. Soil Sci. Soc. Am. J. 72:613-625.

Franzluebbers, A. J., Stuedemann, J. A., Schomberg, H. H. 2000. Spatial distribution of soil carbon and nitrogen pools under grazed tall fescue. Soil Sci. Soc. Am. J.64: 635-639.

Greene, R. S. B., Kinnell, P. I.A., Wood, J. T. 1994. Role of plant cover and stock trampling on runoff and soil erosion from semiarid wooded rangelands. Aust. J. Soil Res. 32: 953-973.

Greenwood, K. L., McKenzie, B. M. 2001. Grazing effects on soil physical properties and the consequences for pastures: a review. Aust. J. Exp. Agr. 41:1231-1250.

Gupta, S. C., Allmaras, R. R. 1987. Models to assess the susceptibility of soils to excessive compaction. Adv. Soil Sci. 6:65-100.

Hamza, M. A. M., Anderson, W. K. 2005. Soil compaction in cropping systems. A review of the nature, causes and possible solutions. Soil Till. Res. 82:121-145.

Lal, R., Mohboubi, A. A., Faussey, R. R. 1994. Long term tillage and rotation effect on properties of a central Ohio Soil. Soil Sci. Soc. Am. J. 58:517522 .

Littell, R. C., Milliken, G. A., Stroup, W. W., Wolfinger, R. D., Schabenberger, O. 2006. SAS ${ }^{\circledR}$ for Mixed Models, second edition. SAS Institute Inc, Cary, NC, USA.

Maughan, M. W., Flores, J. P. C., Anghinoni, I., Bollero, G., Fernandez, F. G., Tracy, B. 2009. Soil quality and corn yield under crop-livestock integration in Illinois. Agr. J. 101: 1503-1510.
Munkholm, L. J., Schjonning, P., Rasmussen, K. J., Tanderup, K. 2003. Spatial and temporal effects of direct drilling on soil structure in the seedling environment. Soil Till. Res. 71:163-173.

Pietola, L., Horn, H., Yli-Halla, M. 2005. Effects of trampling by cattle on the hydraulic and mechanical properties. Soil Till. Res. 82: 98-108.

Quiroga, A., Fernandez, R., Noellemeyer, E. 2009. Grazing effect on soil properties in conventional and no-till systems. Soil Till.Res. 105:164-170

Ritchie, S. W., Hanway, J. J. 1982. How a corn plant develops. Iowa State University of Science and Technology. Cooperative Extension Service. Ames, Iowa, EEUU. Special report No 48.24 p.

Rizzalli, R. H., 1998. Siembra directa y convencional de maiz ante distintas ofertas de nitrógeno. Tesis. Universidad Nacional de Mar del Plata, Facultad de Ciencias Agrarias, Unidad Integrada Balcarce, Argentina. Argentina. $60 \mathrm{p}$.

Sasal, M. C., Andriulo, A. E., Taboada, M.A. 2006. Soil porosity characteristics and water movement under zero tillage in silty soils in Argentinian Pampas. Soil Till. Res. 87: 9-18.

Taboada, M. A., Micucci, F. G., Cosentino, D. J., Lavado, R. S. 1998. Comparison of compaction induced by conventional and zero tillage in two soils of the Rolling Pampa of Argentina. Soil Till. Res.49:57-63.

Wu, L., Pan, L., Mitchell, J., Sanden, B. 1999. Measuring saturated hydraulic conductivity using a generalized solution for single-ring infiltrometer. Soil Sci. Soc. Am. J. pp. 1318-1322.

Zhang, B., Horn, R., Hallett, P. D. 2005. Mechanical resilience of degrade soil amended with organic matter. Soil Sci. Soc. Am. J. 69:864-871. 